\title{
Development of "Imprint-and-Report" Dynamic Combinatorial Libraries for Differential Sensing Applications
}

Emily E. Harrison, Benjamin A. Carpenter, Marcey L. Waters*

Department of Chemistry, CB 3290, University of North Carolina at Chapel Hill, Chapel Hill, North Carolina 27599, United States

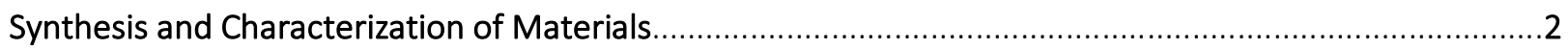

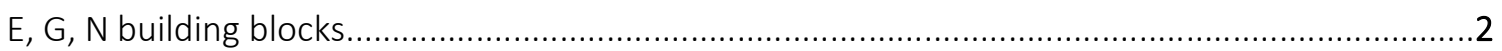

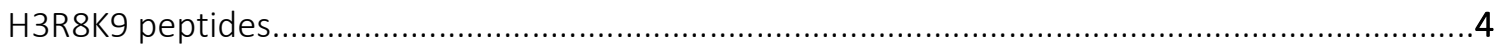

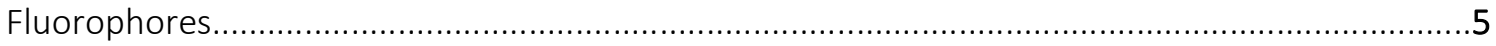

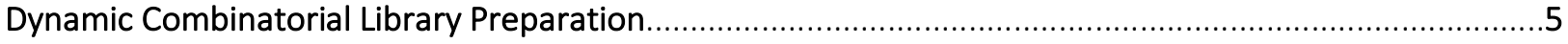

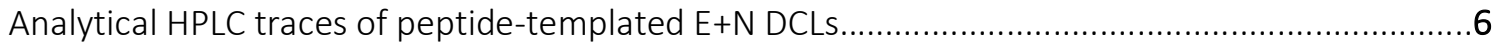

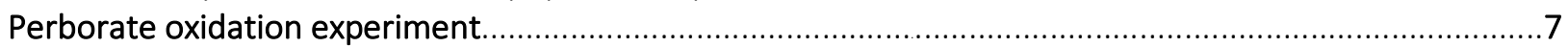

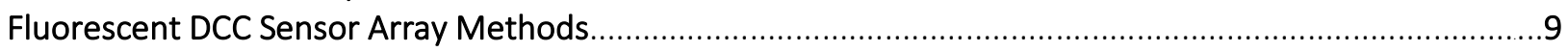

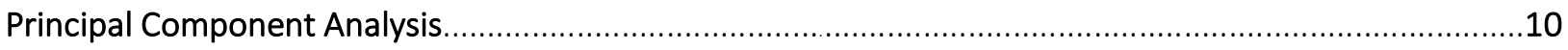

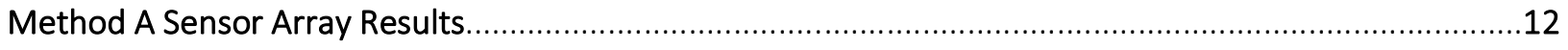

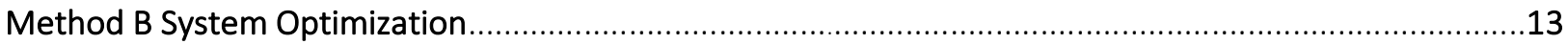

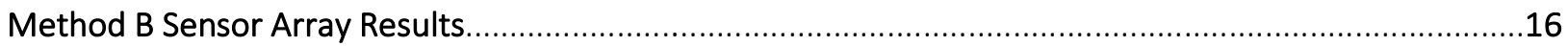

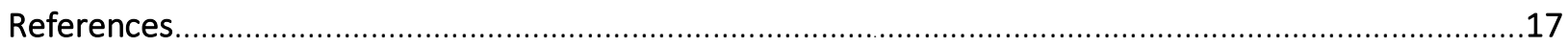




\section{Synthesis and Characterization of Materials}

Building Blocks. Exchangeable building blocks (BBs) $E,{ }^{1} \mathrm{G},{ }^{2}$ and $\mathrm{N}^{3}$ were synthesized according to previously described literature procedures. The prepared materials were stored in nitrogen-filled vials sealed with Parafilm to prevent oxidation. Extinction coefficients were measured for each BB in $50 \mathrm{mM}$ borate buffer $(\mathrm{pH} 8.5)$ at $267 \mathrm{~nm}$ and $280 \mathrm{~nm}$. Three measurements of each sample were taken at each wavelength and averaged.

BB E: $10.0 \mathrm{mg}$ was dissolved in $25.0 \mathrm{~mL}$ buffer. Serial dilutions were made to achieve the concentration range $1230 \mu \mathrm{M}-77.1 \mu \mathrm{M}$.

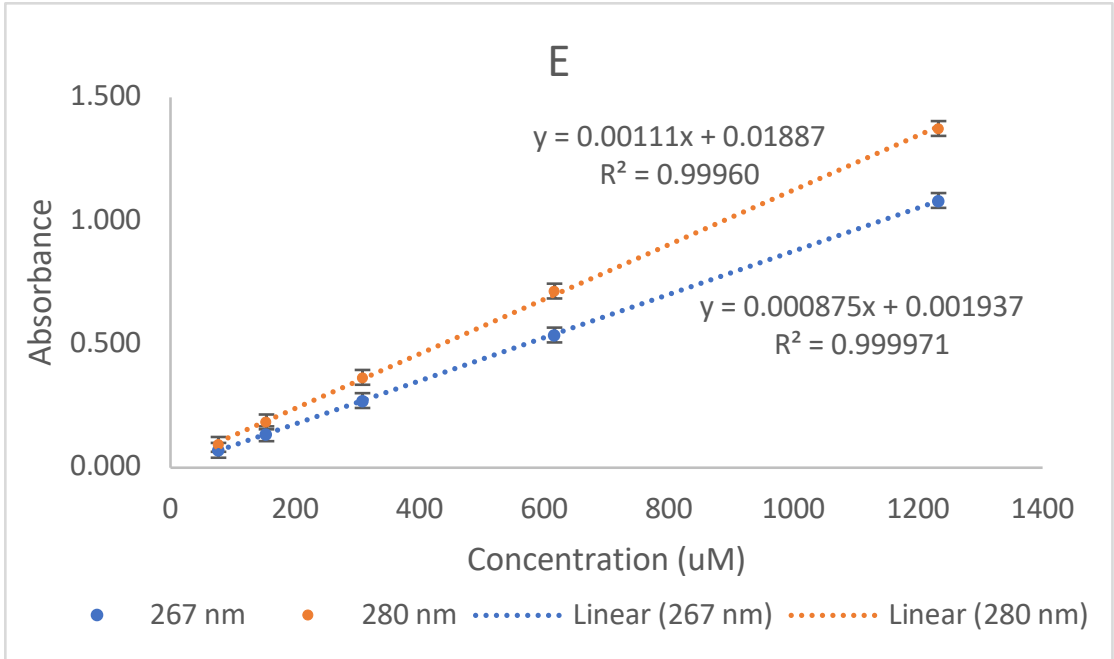

Figure S1. Plot of Abs versus concentration of BB E stocks to determine extinction coefficients. Abs was measured at $267 \mathrm{~nm}$ (blue) and $280 \mathrm{~nm}$ (orange). A standard error of +/- 0.03 for each Abs point was estimated.

BB G: $6.44 \mathrm{mg}$ was dissolved in $25.0 \mathrm{~mL}$ buffer. Serial dilutions were made to achieve the concentration range $500 \mu \mathrm{M}-31.3 \mu \mathrm{M}$.

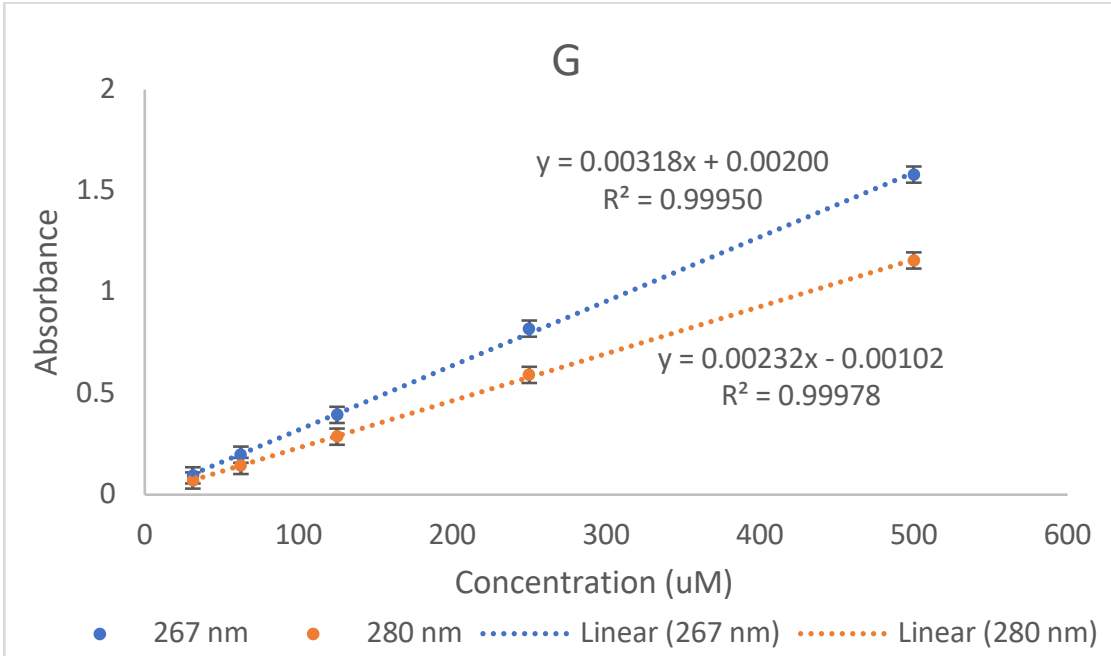

Figure S2. Plot of Abs versus concentration of BB G stocks to determine extinction coefficients. Abs was measured at $267 \mathrm{~nm}$ (blue) and $280 \mathrm{~nm}$ (orange). A standard error of +/- 0.03 for each Abs point was estimated. 
BB N: $5.57 \mathrm{mg}$ was dissolved in $10.0 \mathrm{~mL}$ buffer. Serial dilutions were made to achieve the concentration range $1000 \mu \mathrm{M}-62.5 \mu \mathrm{M}$.

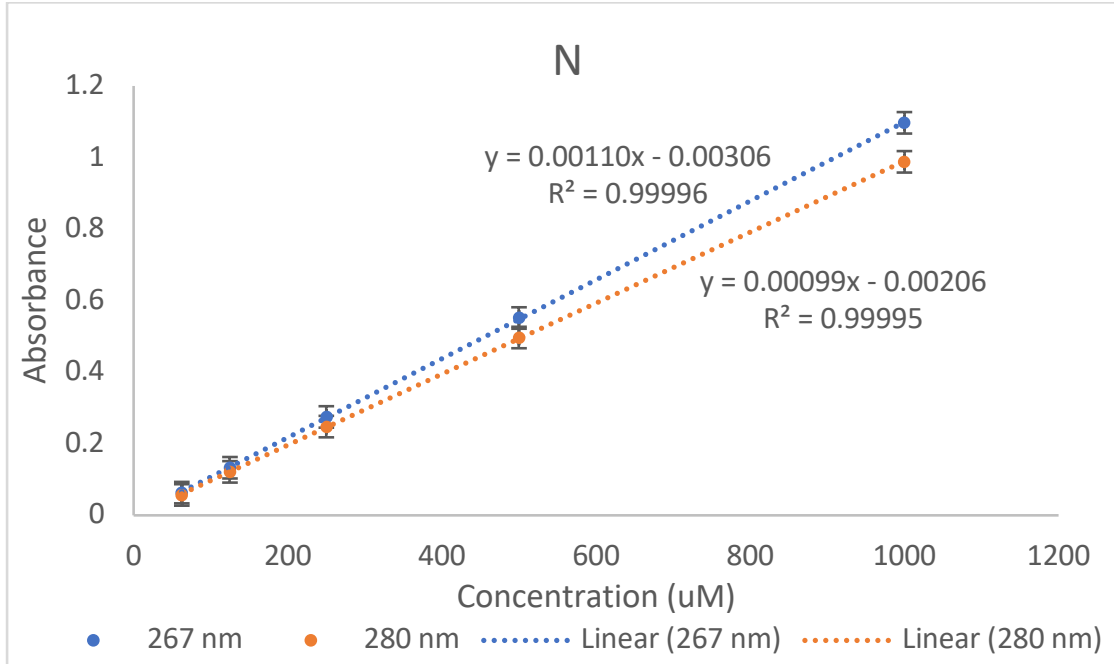

Figure S3. Plot of Abs versus concentration of BB N stocks to determine extinction coefficients. Abs was measured at $267 \mathrm{~nm}$ (blue) and $280 \mathrm{~nm}$ (orange). A standard error of $+/-0.03$ for each Abs point was estimated.

Table S1. Measured extinction coefficients of BBs E, G, and N at $267 \mathrm{~nm}$ and $280 \mathrm{~nm}$ used for concentration determination.

\begin{tabular}{|c|c|c|}
\hline BB & $\begin{array}{c}\text { Extinction Coeff. @ } \\
267 \mathrm{~nm}\left(\mathrm{M}^{-1} \mathrm{~cm}^{-1}\right)\end{array}$ & $\begin{array}{c}\text { Extinction Coeff. @ } \\
280 \mathrm{~nm}\left(\mathrm{M}^{-1} \mathrm{~cm}^{-1}\right)\end{array}$ \\
\hline $\mathrm{E}$ & 8,750 & 11,100 \\
\hline G & 31,800 & 23,200 \\
\hline $\mathrm{N}$ & 11,000 & 9,900 \\
\hline
\end{tabular}


Table S2. Peptide sequences used in sensor array assays.

\begin{tabular}{|l|l|l|l|}
\hline \multicolumn{1}{|c|}{$\begin{array}{c}\text { Peptide } \\
\text { Abbreviation }\end{array}$} & \multicolumn{1}{|c|}{ Sequence } & \multicolumn{1}{c|}{ MS Calculated } & \multicolumn{1}{c|}{ MS Observed } \\
\hline H3 R8K9 & Ac-YGGQTARKSTG-NH 2 & $\begin{array}{l}1166.6[\mathrm{M}+\mathrm{H}], 583.8 \\
{[\mathrm{M}+2 \mathrm{H}], 389.5[\mathrm{M}+3 \mathrm{H}]}\end{array}$ & $\begin{array}{l}1166.5[\mathrm{M}+\mathrm{H}], 583.8 \\
{[\mathrm{M}+2 \mathrm{H}], 389.6[\mathrm{M}+3 \mathrm{H}]}\end{array}$ \\
\hline H3 R8me1 & Ac-YGGQTARme1KSTG-NH 2 & $\begin{array}{l}1180.6[\mathrm{M}+\mathrm{H}], 590.8 \\
{[\mathrm{M}+2 \mathrm{H}]}\end{array}$ & $\begin{array}{l}1180.5[\mathrm{M}+\mathrm{H}], 591.3 \\
{[\mathrm{M}+2 \mathrm{H}]}\end{array}$ \\
\hline H3 R8me2a & Ac-YGGQTARme2aKSTG-NH 2 & $\begin{array}{l}1195.6[\mathrm{M}+\mathrm{H}], 598.3 \\
{[\mathrm{M}+2 \mathrm{H}]}\end{array}$ & $\begin{array}{l}1195.5[\mathrm{M}+\mathrm{H}], 597.9 \\
{[\mathrm{M}+2 \mathrm{H}]}\end{array}$ \\
\hline H3 R8me2s & Ac-YGGQTARme2sKSTG-NH 2 & $\begin{array}{l}1195.6[\mathrm{M}+\mathrm{H}], 598.3 \\
{[\mathrm{M}+2 \mathrm{H}], 399.2[\mathrm{M}+3 \mathrm{H}]}\end{array}$ & $\begin{array}{l}1195.5[\mathrm{M}+\mathrm{H}], 598.0 \\
{[\mathrm{M}+2 \mathrm{H}], 399.1[\mathrm{M}+3 \mathrm{H}]}\end{array}$ \\
\hline H3 K9me1 & Ac-YGGQTARKme1STG-NH 2 & $\begin{array}{l}1180.6[\mathrm{M}+\mathrm{H}], 590.8 \\
{[\mathrm{M}+2 \mathrm{H}], 394.2[\mathrm{M}+3 \mathrm{H}]}\end{array}$ & $\begin{array}{l}1180.5[\mathrm{M}+\mathrm{H}], 591.0 \\
{[\mathrm{M}+2 \mathrm{H}], 394.3[\mathrm{M}+3 \mathrm{H}]}\end{array}$ \\
\hline H3 K9me2 & Ac-YGGQTARKme2STG-NH 2 & $\begin{array}{l}1194.6[\mathrm{M}+\mathrm{H}], 597.8 \\
{[\mathrm{M}+2 \mathrm{H}]}\end{array}$ & $\begin{array}{l}1195.5[\mathrm{M}+\mathrm{H}], 597.9 \\
{[\mathrm{M}+2 \mathrm{H}]}\end{array}$ \\
\hline H3 K9me3 & Ac-YGGQTARKme3STG-NH 2 & $\begin{array}{l}1208.6[\mathrm{M}+\mathrm{H}], 604.8 \\
{[\mathrm{M}+2 \mathrm{H}], 403.5[\mathrm{M}+3 \mathrm{H}]}\end{array}$ & $\begin{array}{l}1208.6[\mathrm{M}+\mathrm{H}], 604.9 \\
{[\mathrm{M}+2 \mathrm{H}], 403.7[\mathrm{M}+3 \mathrm{H}]}\end{array}$ \\
\hline
\end{tabular}

Peptides. Peptides were synthesized on P3 Biosystems Rink Amide resin ( $0.56 \mathrm{mmol} / \mathrm{g}$ loading) through Fmoc solid-phase peptide synthesis either in a peptide flask or using a LibertyBlue (CEM) microwave peptide synthesizer. For peptides synthesized in a flask using 1 equiv. of resin, coupling solutions for canonical amino acids were comprised of 4 equiv. Fmoc amino acid, 4 equiv. HBTU, 4 equiv. HOBt, and 8 equiv. DIPEA in DMF. These couplings were run for 60 minutes each. For methylated Lys and Arg, couplings were left for 3 hours and only 2 equiv. of Fmoc amino acid was utilized. Fmoc deprotections were run for 30 minutes using $20 \%$ piperidine in DMF. Canonical amino acid couplings performed on the microwave synthesizer were done in DMF for 2 minutes at $90^{\circ} \mathrm{C}$ with 5 equiv. Fmoc amino acid, 10 equiv. DIC, and 5 equiv. Oxyma per 1 equiv. of resin. Canonical amino acids were coupled once, except for Arg, which was coupled twice. All methylated residues were double-coupled with 2 equiv. Fmoc amino acid at $90{ }^{\circ} \mathrm{C}$ for 4 minutes. Deprotections were done using $20 \%$ piperidine in DMF for 90 seconds at $90{ }^{\circ} \mathrm{C}$.

Peptides were $\mathrm{N}$-terminally acetylated while still on resin in a peptide synthesis flask by mixing with a capping solution of 5\% acetic anhydride and 6\% 2,6-lutidine in DMF for 30 minutes. Cleavage and global deprotection of acetylated peptides were performed using 5\% TIPS, 5\% water, and 90\% TFA for 4 hrs. Peptides were purified on a Waters semi-preparative HPLC outfitted with a C18 column with a flow rate of $4 \mathrm{~mL} / \mathrm{min}$. Purification was done using a linear gradient of two eluents, eluent A $(95 \%$ water, $5 \% \mathrm{ACN}$, $0.1 \%$ TFA) and eluent B (95\% ACN, 5\% water, 0.1\% TFA).

All peptides were characterized using an Agilent Rapid Resolution LC-MSD system equipped with online degasser, binary pump, autosampler, heated column compartment, and diode array detector. Samples were run with gradients of $0.2 \%$ formic acid solutions of water and acetonitrile on a C18 column ( $4.6 \mathrm{x}$ $100 \mathrm{~mm}, 2.7 \mathrm{um}$ ). Mass spectra (ESI+) were acquired on a single quad mass spectrometer using a drying temperature of $350^{\circ} \mathrm{C}$, a nebulizer pressure of $45 \mathrm{psi}$, a drying gas flow of $10 \mathrm{~L} / \mathrm{min}$, and a capillary voltage of $3000 \mathrm{~V}$. All peptides used have been previously reported. 
Fluorophores. Lucigenin (LCG), acridine orange (AO), thioflavin T (ThT), and dansyl choline are all commercially available fluorophores that were purchased and used as received.

FAM-Nme ${ }_{3}{ }^{+}$was synthesized according to a published literature procedure ${ }^{4}$ and stored frozen in a sealed, nitrogen-filled tube.

Table S3. Extinction coefficients of fluorophores used for concentration determinations.

\begin{tabular}{|c|c|}
\hline Dye & $\begin{array}{c}\text { Extinction Coefficient used } \\
\left(\mathbf{M}^{-1} \mathrm{~cm}^{-1}\right)\end{array}$ \\
\hline LCG & $33,000 @ 367 \mathrm{~nm}^{5}$ \\
\hline AO & $27,000 @ 431 \mathrm{~nm}^{6}$ \\
\hline ThT & $36,000 @ 412 \mathrm{~nm}^{7}$ \\
\hline FAM-Nme3+ & $75,000 @ 495 \mathrm{~nm}^{8}$ \\
\hline Dansyl choline & $4,350 @ 315 \mathrm{~nm}^{9}$ \\
\hline
\end{tabular}

\section{Dynamic Combinatorial Library Preparation and Characterization}

The dynamic combinatorial libraries (DCLs) were prepared fresh for each experiment to allow disulfide exchange to occur in the presence of the appropriate template and to maintain consistency in equilibration time. BB stocks were measured by mass $(3-5 \mathrm{mg}$ ) and dissolved in $1-2 \mathrm{~mL} 50 \mathrm{mM}$ borate buffer ( $\mathrm{pH}$ 8.5). If monomer dissolution was not progressing, a small aliquot $(10 \mu \mathrm{L})$ of $1 \mathrm{M} \mathrm{NaOH}$ was added followed by sonication. BB concentrations were validated using UV/Vis and their respective extinction coefficients (Table S1).

Method A. Peptide stock solutions were made by dissolving lyophilized peptide in $50 \mathrm{mM}$ borate buffer ( $\mathrm{pH}$ 8.5), and concentration was determined using UV/Vis and the extinction coefficient of Tyr at $280 \mathrm{~nm}$ $\left(1,490 \mathrm{M}^{-1} \mathrm{~cm}^{-1}\right)^{10}$. The final concentration of peptide in all templated libraries was $1.35 \mathrm{mM}$. Additionally, the total concentration of BB was $1.35 \mathrm{mM}$ for all libraries. For each BB combination, a DCL was made containing no peptide as a "No Guest" control. The concentrations of individual BBs in each library are as follows:

- E+G libraries: $0.67 \mathrm{mM} \mathrm{E}$ and $0.67 \mathrm{mM} \mathrm{G}$

- E+N libraries: $0.67 \mathrm{mM} \mathrm{E}$ and $0.67 \mathrm{mM} \mathrm{N}$

- G+N libraries: $0.67 \mathrm{mM} \mathrm{G}$ and $0.67 \mathrm{mM} \mathrm{N}$

- $\mathrm{E}+\mathrm{G}+\mathrm{N}$ libraries: $0.67 \mathrm{mM} \mathrm{G}, 0.34 \mathrm{mM}$, and $0.34 \mathrm{mM} \mathrm{N}$

Method B. Dye stock solutions were made by dissolving fluorophore in $50 \mathrm{mM}$ borate buffer ( $\mathrm{pH} 8.5$ ) and concentration was determined using UV/Vis and the reported literature extinction coefficient of the dye (Table S3). The final concentration of dye in all templated libraries was $1.00 \mathrm{mM}$. Additionally, the total concentration of BB was 1.00 mM for all libraries. The concentrations of individual BBs in each library are as follows:

- $E+G$ libraries: $0.50 \mathrm{mM} \mathrm{E}$ and $0.50 \mathrm{mM} \mathrm{G}$

- E+N libraries: $0.50 \mathrm{mM} E$ and $0.50 \mathrm{mM} \mathrm{N}$

- G+N libraries: $0.50 \mathrm{mM} \mathrm{G}$ and $0.50 \mathrm{mM} \mathrm{N}$

- $\mathrm{E}+\mathrm{G}+\mathrm{N}$ libraries: $0.50 \mathrm{mM} \mathrm{G}, 0.25 \mathrm{mM} \mathrm{E}$, and $0.25 \mathrm{mM} \mathrm{N}$

Libraries were equilibrated for 5 days with gentle shaking to allow thermodynamic equilibrium to be reached. To identify speciation, E+N libraries were characterized on a Waters analytical HPLC outfitted 
with a C18 column. Two eluents were used, eluent $\mathrm{A}\left(10 \mathrm{mM} \mathrm{NH}_{4} \mathrm{OAc}\right.$ in water) and eluent $\mathrm{B}$ (10 mM $\mathrm{NH}_{4} \mathrm{OAc}$ in $10 \%$ water, $90 \% \mathrm{ACN}$ ). Libraries were run using a gradient of $0-100 \% \mathrm{~B}$ in 60 min with a flow rate of $1.0 \mathrm{~mL} / \mathrm{min}$. Library species were further characterized using an Agilent Rapid Resolution LC-MSD system equipped with online degasser, binary pump, autosampler, heated column compartment, and diode array detector. Samples were run with gradients of $10 \mathrm{mM} \mathrm{NH}_{4} \mathrm{OAc}$ solutions in water and ACN. Libraries were run on a C18 column. Mass spectra (ESI-) were acquired on a single quad mass spectrometer using a drying temperature of $350^{\circ} \mathrm{C}$, a nebulizer pressure of $45 \mathrm{psi}$, a drying gas flow of 10 $\mathrm{L} / \mathrm{min}$, and a capillary voltage of $3000 \mathrm{~V}$. $\mathrm{E}+\mathrm{G}, \mathrm{N}+\mathrm{G}$, and $\mathrm{E}+\mathrm{N}+\mathrm{G}$ DCLs (untemplated and templated with each Arg and Lys methylation state) have been previously characterized and reported. ${ }^{11}$
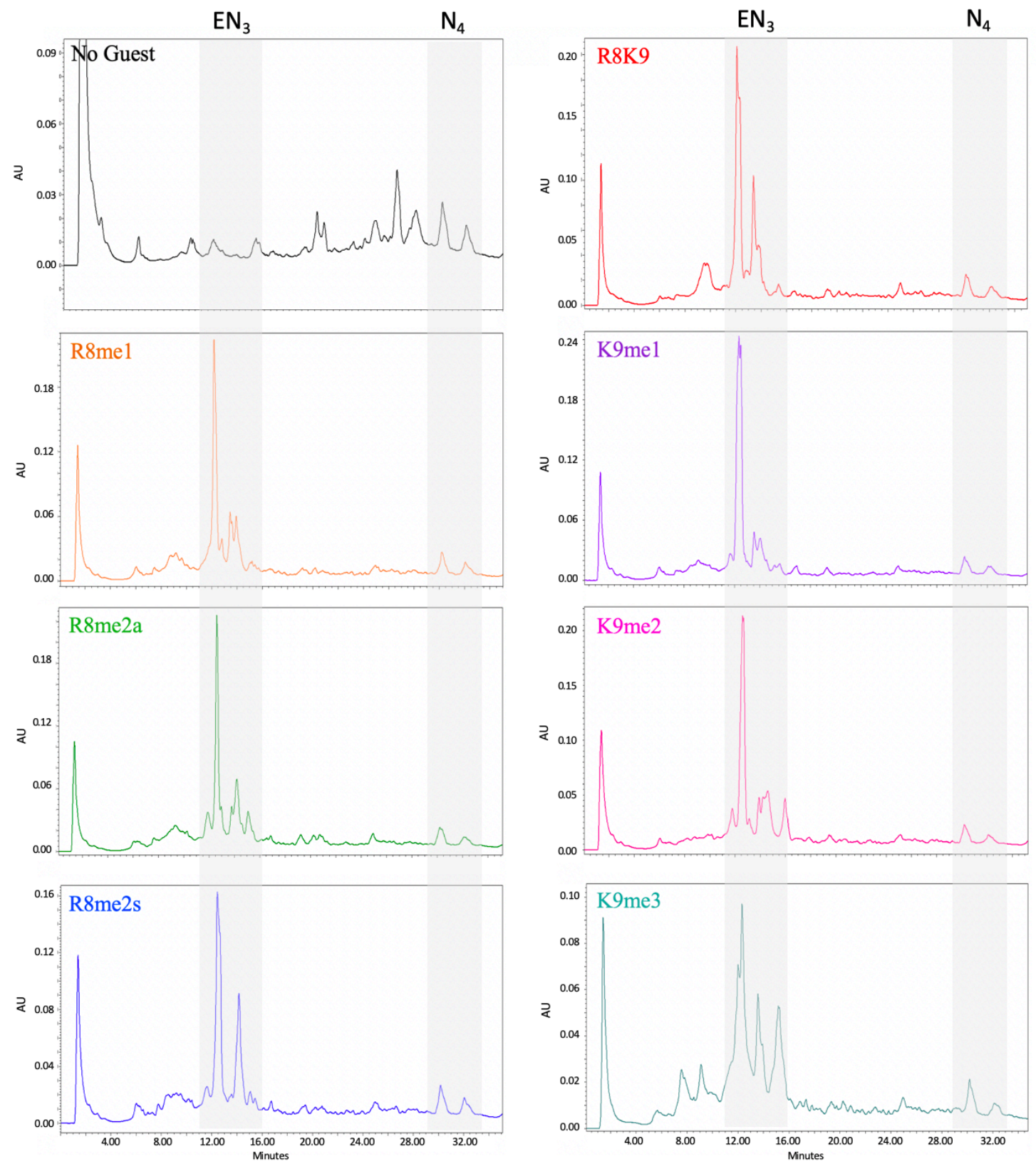

Figure S4. Analytical HPLC traces of the E+N DCL untemplated and templated with H3R8K9 peptides containing each methylation state of Arg and Lys. 
Verification of Full DCL Oxidation. To ensure DCLs were fully oxidized and equilibrated after 5 days for use in fluorescence assays, a comparison was made between DCLs with and without the chemical oxidant sodium perborate tetrahydrate. The full set of $32 \mathrm{DCLs}(E+G, N+G, E+N, E+N+G$ with each of the 7 peptides and a 'No Guest' control) were set up as described above (see Dynamic Combinatorial Library Preparation and Characterization under Method A). After 5 days, each library was divided in half and one half was treated with 1 equivalent of perborate $(185 \mu \mathrm{L} \mathrm{DCL}+5 \mu \mathrm{L} 51.3 \mathrm{mM}$ perborate solution in sodium borate buffer at $\mathrm{pH}$ 8.5). After allowing 1 hour for oxidation of any unoxidized DCL species by the perborate, these DCLs as well as those that were oxidized only by exposure to air were analyzed on a Waters analytical HPLC outfitted with a C18 column using eluent $\mathrm{A}$ (10 $\mathrm{mM} \mathrm{NH}_{4} \mathrm{OAc}$ in water) and eluent $\mathrm{B}\left(10 \mathrm{mM} \mathrm{NH}_{4} \mathrm{OAc}\right.$ in $10 \%$ water, $\left.90 \% \mathrm{ACN}\right)$. Libraries were run using a gradient of $15-55 \% \mathrm{~B}$ in $15 \mathrm{~min}$ with a flow rate of $1.0 \mathrm{~mL} / \mathrm{min}$. A qualitative comparison of the analytical traces reveals that speciation is comparable in DCLs with and without perborate, indicating that oxidation had completed in the 5-day period before the perborate was added.
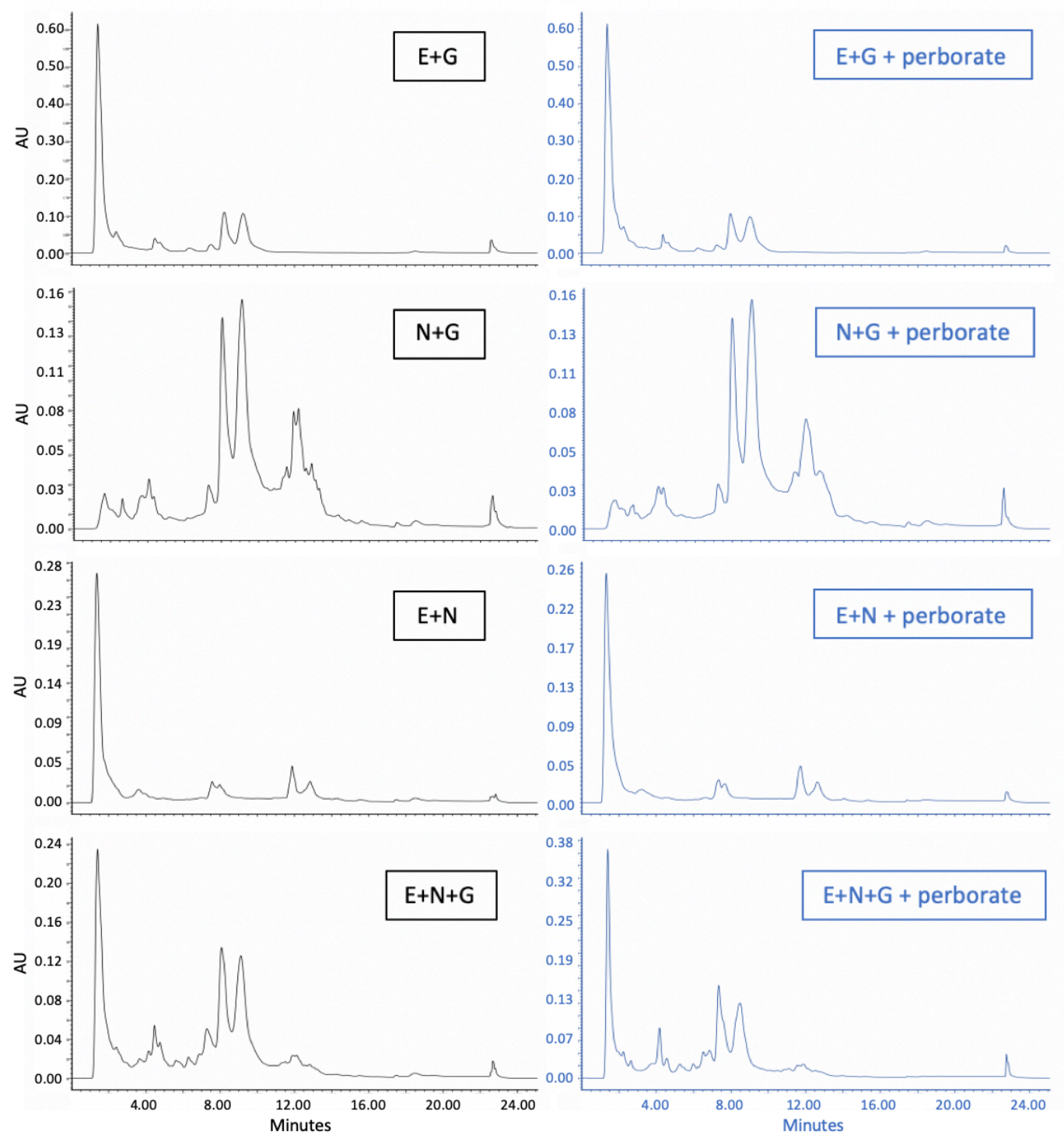

Figure S5. Analytical HPLC traces of the untemplated $E+G, N+G, E+N$, and $E+N+G$ DCLs after 5 days of equilibration with and without the chemical oxidant perborate added. 
Each set of these DCLs was also used to run a fluorescent DCC assay (see full protocol below in Fluorescent-DCC Sensor Array Assays under Method A). Results were visualized as normalized fluorescence in Fig. S6 for each PTM and further demonstrate that speciation and therefore fluorescence outputs are comparable with and without the addition of perborate. Thus, a 5-day DCL equilibration period was deemed sufficient.

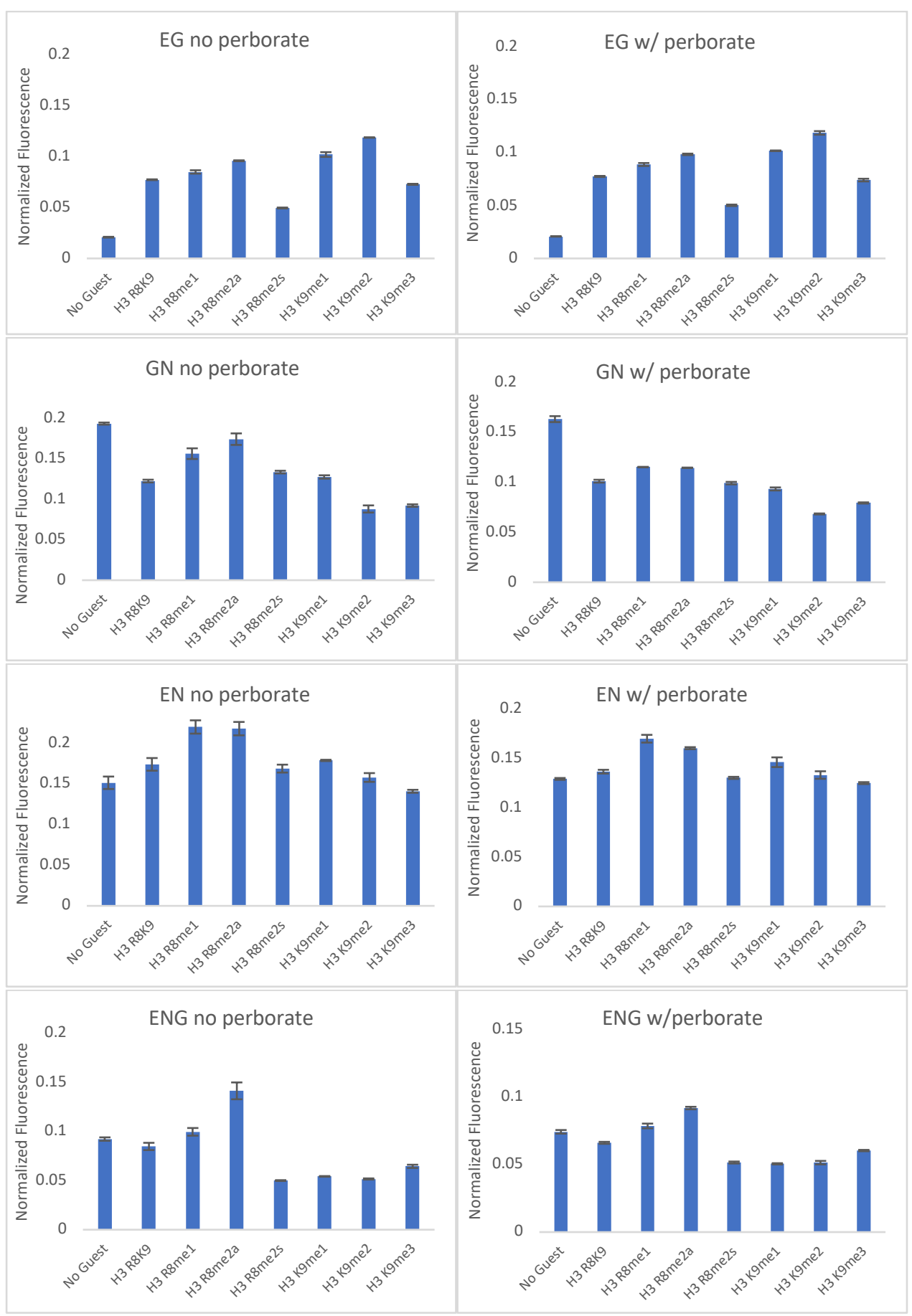

Figure S6. Normalized fluorescence of DCLs templated with each H3R8K9 peptide and doped with LCG. One set of DCLs was oxidized strictly via exposure to air (left column), while another set was oxidized first with air followed by perborate (right column). 


\section{Fluorescent-DCC Sensor Array Assays}

Method A. Stock solutions ( $5 \mu \mathrm{M}$ ) were made up of each fluorescent dye in $50 \mathrm{mM}$ borate buffer ( $\mathrm{pH}$ 8.5). Concentrations were determined using published extinction coefficients for AO, ThT, and LCG (Table S3). After DCLs equilibrated for 5 days, $160 \mu \mathrm{L}$ of library was mixed with $40 \mu \mathrm{L}$ of the dye stock solution, resulting in $1.08 \mathrm{mM}$ peptide, $1.08 \mathrm{mM}$ total monomer, and $1 \mu \mathrm{M}$ dye. These solutions were vortexed and left to incubate for 30 minutes. Ten replicate samples ( $75 \mu \mathrm{L}$ each) for each mixture were pipetted into Corning 384-well non-binding, black-bottom plates, and these plates were subsequently spun down at 4,000 rpm for 5 minutes.

Top-down fluorescence measurements were made using a BMG Labtech POLARStar Omega plate reader. The gain was set automatically by the Omega software using a $1 \mu \mathrm{M}$ solution of dye in $50 \mathrm{mM}$ borate buffer ( $\mathrm{pH}$ 8.5) without any BBs or peptide. Libraries doped with either AO or ThT were excited at $485 \mathrm{~nm}$ and emission was measured at $510 \mathrm{~nm}$. Libraries doped with LCG were excited at $370 \mathrm{~nm}$ and emission was measured at $510 \mathrm{~nm}$.

Method B. Stock solutions ( $10 \mu \mathrm{M})$ were made up of each peptide in $50 \mathrm{mM}$ borate buffer $(\mathrm{pH} 8.5)$. Concentrations were determined using the extinction coefficient of Tyr at $280 \mathrm{~nm}\left(1,490 \mathrm{M}^{-1} \mathrm{~cm}^{-1}\right)$. After DCLs equilibrated for 5 days, each one was diluted 100-fold (10 $\mu \mathrm{L} \mathrm{DCL}+990 \mu \mathrm{L}$ buffer) and distributed among eight samples, each ultimately containing $20 \mu \mathrm{L}$ diluted $\mathrm{DCL}, 100 \mu \mathrm{L}$ peptide stock (or buffer in the case of the "No Guest" control), and $880 \mu \mathrm{L}$ buffer. This resulted in final concentrations of $200 \mathrm{nM}$ total BBs, $200 \mathrm{nM}$ dye, and $1 \mu \mathrm{M}$ peptide. These solutions were vortexed and left to incubate for 1 hour with gentle shaking. Six replicate samples (50 $\mu \mathrm{L}$ each) for each mixture were pipetted into Corning 384-well non-binding, black-bottom plates, and these plates were subsequently spun down at 4,000 rpm for 5 minutes.

Top-down fluorescence measurements were made using a BMG Labtech POLARStar Omega plate reader. The gain was set automatically by the Omega software using a $200 \mathrm{nM}$ solution of dye in $50 \mathrm{mM}$ borate buffer ( $\mathrm{pH}$ 8.5) without any BBs or peptide. Libraries with LCG were excited at $370 \mathrm{~nm}$ and emission was measured at $510 \mathrm{~nm}$. Those with dansyl choline were excited at $290 \mathrm{~nm}$ and measured at $510 \mathrm{~nm}$, and those containing FAM-Nme ${ }_{3}{ }^{+}$were excited at $485 \mathrm{~nm}$ and emission was measured at $510 \mathrm{~nm}$.

\section{Principal Component Analysis Workup}

All assay data was visualized via principal component analysis (PCA). PCA was plotted with confidence ellipses using RStudio version 1.2.1335. Prior to being exported to RStudio, the replicates of each data set were sorted from lowest to highest (Table S4), and each fluorescence value was normalized by dividing the raw fluorescence of each sample by the average fluorescence of the dye standard (Table S5). Since PCA requires the same number of data points for each analyte, removal of an outlier for a single analyte would require removing a data point for every analyte. To eliminate bias, a protocol was adopted where the highest and lowest data points were removed from each data set prior to PCA, resulting in 4 replicates per sample. Normalized fluorescence results were also visualized in bar graph form for facile visual comparison (Fig. S7). 
Example of the data work-up for one $D C L(E+G+L C G$; Method $B)$ is below.

Table S4. E+G+LCG (Method B) raw fluorescence measurements with each PTM guest. Each column is sorted from lowest to highest fluorescence.

\begin{tabular}{|c|c|c|c|c|c|c|c|c|c|}
\hline Replicate & $\begin{array}{c}\text { LCG } \\
\text { Standard }\end{array}$ & $\begin{array}{c}\text { No } \\
\text { Guest }\end{array}$ & $\begin{array}{c}\text { H3 } \\
\text { R8K9 }\end{array}$ & $\begin{array}{c}\text { H3 } \\
\text { R8me1 }\end{array}$ & $\begin{array}{c}\text { H3 } \\
\text { R8me2a }\end{array}$ & $\begin{array}{c}\text { H3 } \\
\text { R8me2s }\end{array}$ & $\begin{array}{c}\text { H3 } \\
\text { K9me1 }\end{array}$ & $\begin{array}{c}\text { H3 } \\
\text { K9me2 }\end{array}$ & $\begin{array}{c}\text { H3 } \\
\text { K9me3 }\end{array}$ \\
\hline $\mathbf{1}$ & 210278 & 179211 & 205534 & 192660 & 194367 & 181383 & 199423 & 213795 & 207106 \\
\hline $\mathbf{2}$ & 211503 & 184535 & 205537 & 194179 & 198317 & 183068 & 203174 & 215569 & 208396 \\
\hline $\mathbf{3}$ & 211734 & 185990 & 206029 & 194222 & 201231 & 183320 & 203922 & 215976 & 210287 \\
\hline $\mathbf{4}$ & 211759 & 186576 & 206604 & 194453 & 204623 & 186330 & 208109 & 216819 & 210417 \\
\hline $\mathbf{5}$ & 215623 & 186633 & 207665 & 195957 & 205607 & 187078 & 210030 & 217037 & 215376 \\
\hline $\mathbf{6}$ & 216248 & 188390 & 208219 & 198750 & 207987 & 188386 & 210697 & 218247 & 216219 \\
\hline
\end{tabular}

Table S5. Data from Table S4 normalized by dividing each fluorescence value by the average LCG standard fluorescence. The highest and lowest replicates have been removed, and the average and standard deviation have been included for each guest.

\begin{tabular}{|c|c|c|c|c|c|c|c|c|}
\hline Replicate & No Guest & H3 R8K9 & $\begin{array}{c}\text { H3 } \\
\text { R8me1 }\end{array}$ & $\begin{array}{c}\text { H3 } \\
\text { R8me2a }\end{array}$ & $\begin{array}{c}\text { H3 } \\
\text { R8me2s }\end{array}$ & $\begin{array}{c}\text { H3 } \\
\text { K9me1 }\end{array}$ & $\begin{array}{c}\text { H3 } \\
\text { K9me2 }\end{array}$ & $\begin{array}{c}\text { H3 } \\
\text { K9me3 }\end{array}$ \\
\hline 2 & 0.866942 & 0.965608 & 0.912249 & 0.931689 & 0.860050 & 0.954507 & 1.01274 & 0.979040 \\
\hline 3 & 0.873777 & 0.967920 & 0.912451 & 0.945379 & 0.861233 & 0.958021 & 1.01465 & 0.987924 \\
\hline 4 & 0.876530 & 0.970621 & 0.913536 & 0.961314 & 0.875374 & 0.977692 & 1.01861 & 0.988535 \\
\hline \multirow[t]{2}{*}{5} & 0.876798 & 0.975606 & 0.920602 & 0.965937 & 0.878888 & 0.986716 & 1.01964 & 1.01183 \\
\hline & No Guest & H3 R8K9 & $\begin{array}{c}\text { H3 } \\
\text { R8me1 }\end{array}$ & $\begin{array}{c}\mathrm{H} 3 \\
\mathrm{R} 8 \mathrm{me} 2 \mathrm{a}\end{array}$ & $\begin{array}{c}\text { H3 } \\
\text { R8me2s }\end{array}$ & $\begin{array}{c}\mathrm{H3} \\
\mathrm{K} 9 \mathrm{me1}\end{array}$ & $\begin{array}{c}\text { H3 } \\
\text { K9me2 }\end{array}$ & $\begin{array}{c}\text { H3 } \\
\text { K9me3 }\end{array}$ \\
\hline Average & 0.873512 & 0.969939 & 0.914709 & 0.951080 & 0.868886 & 0.969234 & 1.01641 & 0.991833 \\
\hline St. Dev. & 0.003973 & 0.003722 & 0.003437 & 0.013546 & 0.008349 & 0.013414 & 0.00282 & 0.012143 \\
\hline
\end{tabular}

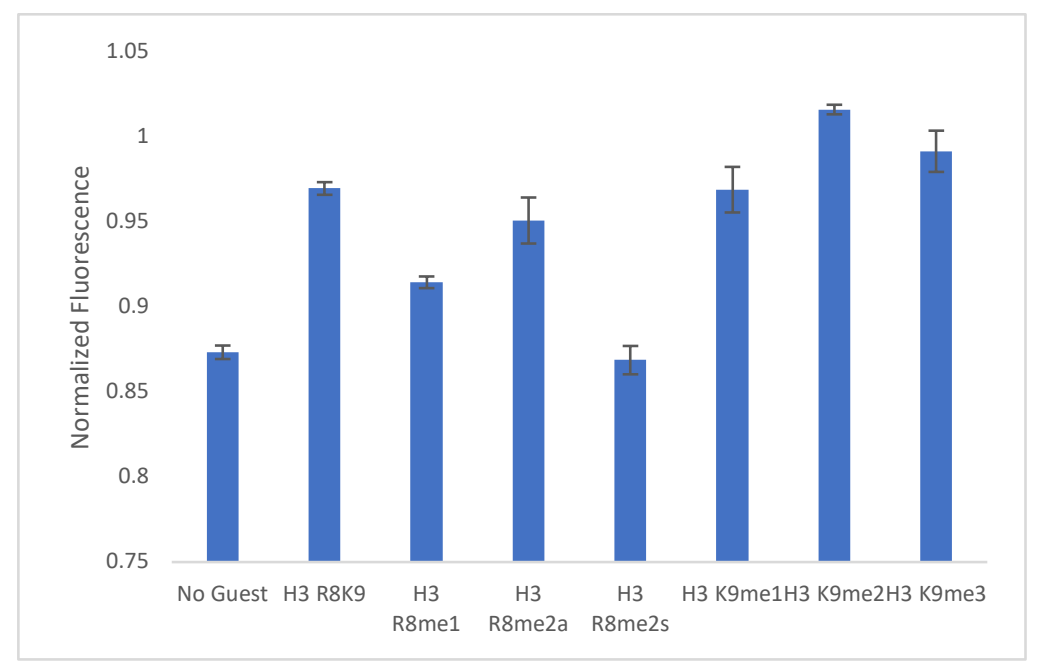

Figure S7. Bar graph of normalized fluorescence for each PTM guest within the $E+G+L C G D C L$. 
This process was repeated for each DCL that was analyzed. Data from Table S5 was then formatted as a comma-separated list as follows:

$0.866942,0.965608,0.912249,0.931689,0.860050,0.954507,1.01274,0.979040$,

$0.873777,0.967920,0.912451,0.945379,0.861233,0.958021,1.01465,0.987924$,

$0.876530,0.970621,0.913536,0.961314,0.875374,0.977692,1.01861,0.988535$,

$0.876798,0.975606,0.920602,0.965937,0.878888,0.986716,1.01964,1.01183$

Data lists in this format were input into RStudio for each DCL. The code below was used to generate PCA plots with at least $85 \%$ confidence ellipses ( $\boldsymbol{x}=0.85$ or above).

DCL_1 <-c([insert comma-separated data list])

DCL_2 <-c([insert comma-separated data list])

DCL_3 <-c([insert comma-separated data list])

PTM <-c("No Guest", "RK", "Rme1", "Rme2a", "Rme2s", "Kme1", "Kme2", "Kme3")

DCCdf <- data.frame(DCL_1, DCL_2, DCL_3, PTM)

DCCdf.pca <- prcomp (DCCdf $[, \mathrm{c}(1,2,3)]$, center=TRUE, scale. $=$ TRUE)

DCCdf.pca

str(DCCdf.pca)

ggbiplot $($ DCCdf.pca, ellipse $=$ TRUE, ellipse $\cdot$ prob $=\boldsymbol{x}$, groups $=$ PTM $)$ 
Method A PCA Sensor Array Identification.

(a)
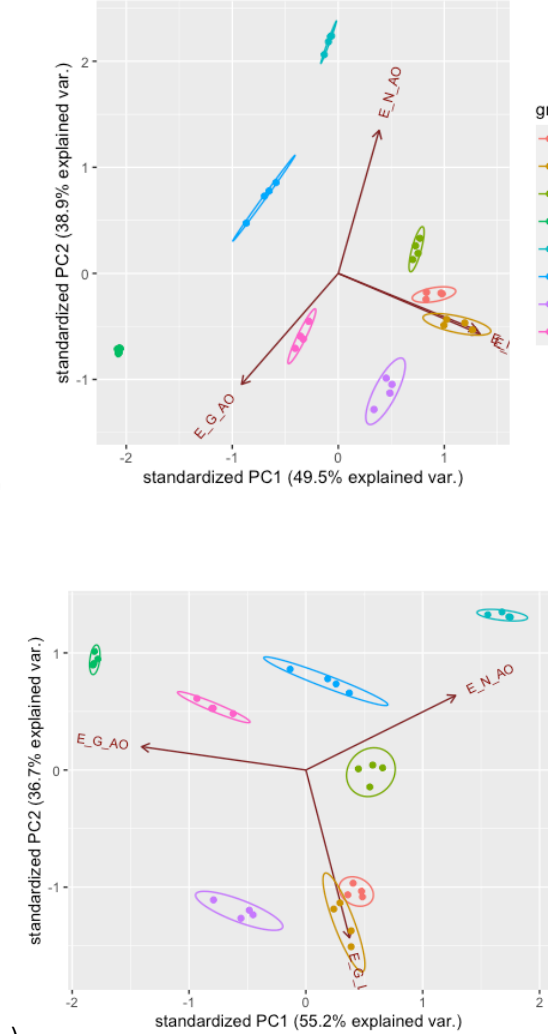

(c)

groups

$\rightarrow$ K9me1

$\rightarrow$ K9me3

$\rightarrow$ No Guest

$\rightarrow$ R8K9

$\rightarrow$ R8me1

$\rightarrow$ R8me2s

(d)
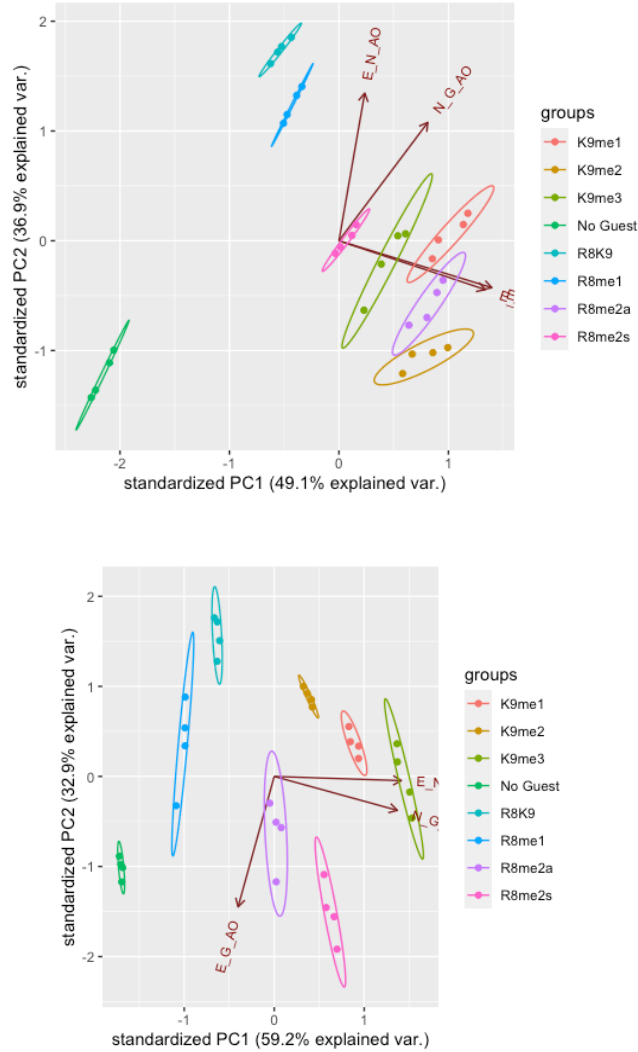

(e)

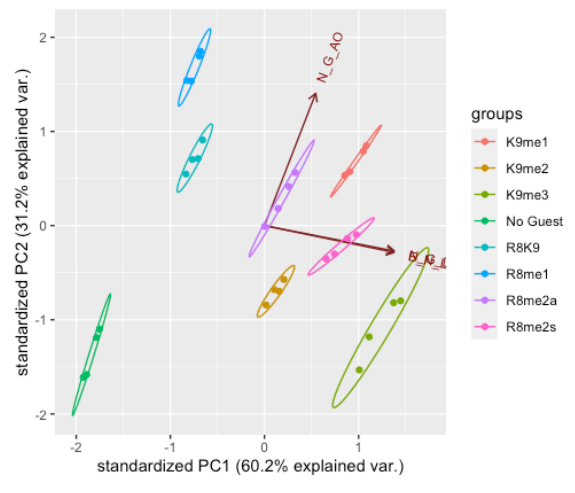

Figure S8. PCA plots from Method A DCL combinations that yielded full separation of all PTMs at $95 \%$ confidence. (a) $E+G / L C G, E+N / L C G, E+G / A O, E+N / A O$. (b) $E+G / L C G, E+N / L C G, N+G / A O, E+N / A O$. (c) $E+G / L C G, E+G / A O, E+N / A O$. (d) N+G/LCG, E+N/LCG, E+G/AO. (e) N+G/LCG, E+N/LCG, N+G/AO. 


\section{Method B System Optimization.}

1:1:1

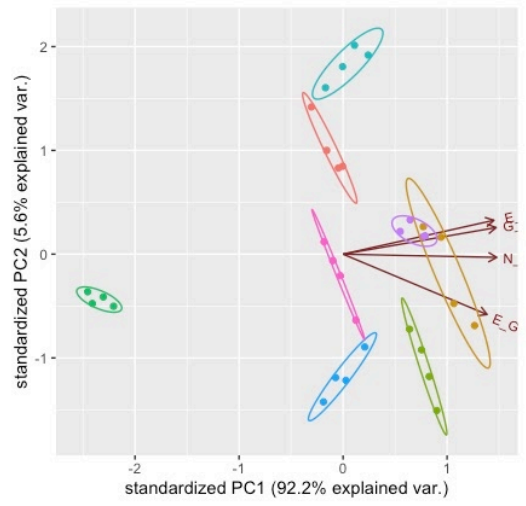

$1: 1: 5$

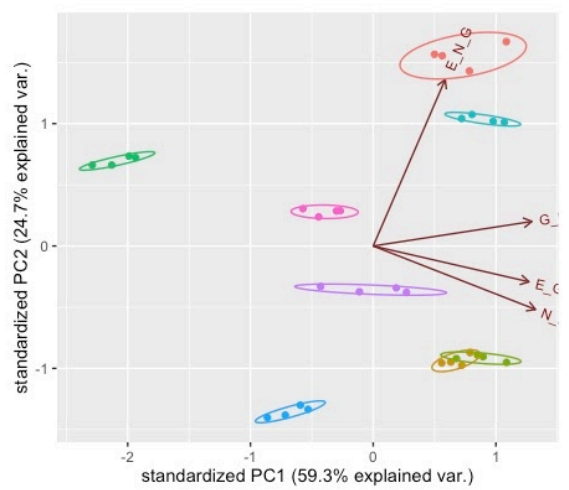

$1: 1: 3$

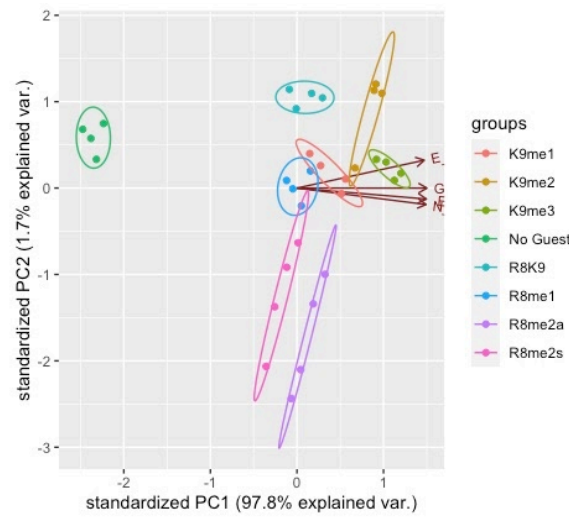

$1: 1: 10$

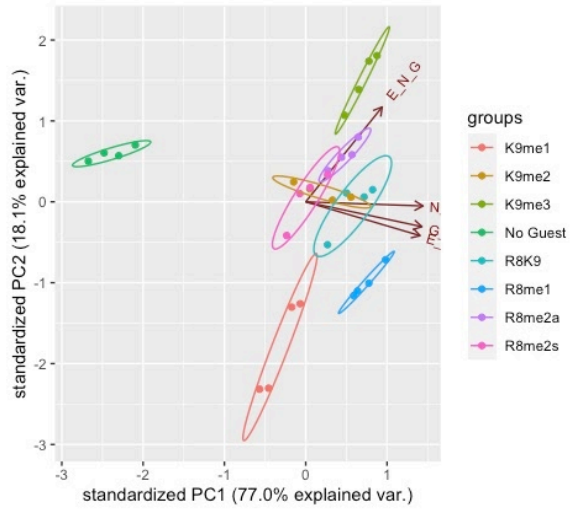

Figure S9. $P C A$ plots resulting from Method $B$ assays with varying ratios of $B B$ to dye to peptide. 1:1:1 = 1 $\mu \mathrm{M} \mathrm{BB}$, dye, and peptide. 1:1:3 = $330 \mathrm{nM} \mathrm{BB}$ and dye, $1 \mathrm{uM}$ peptide. 1:1:5 = $200 \mathrm{nM}$ BB and dye, $1 \mu \mathrm{M}$ peptide. 1:1:10 = $100 \mathrm{nM} \mathrm{BB}$ and dye, $1 \mu \mathrm{M}$ peptide. 


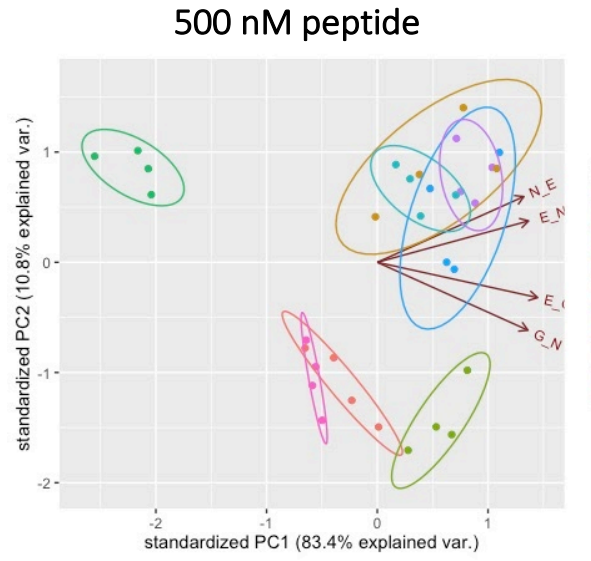

$5 \mu \mathrm{M}$ peptide

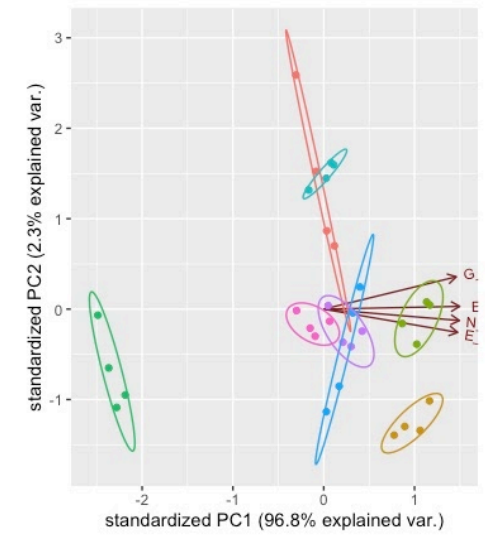

$1 \mu \mathrm{M}$ peptide

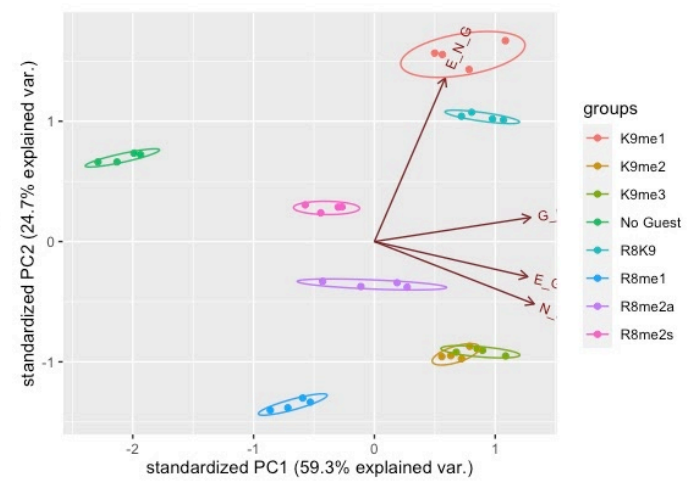

$10 \mu \mathrm{M}$ peptide

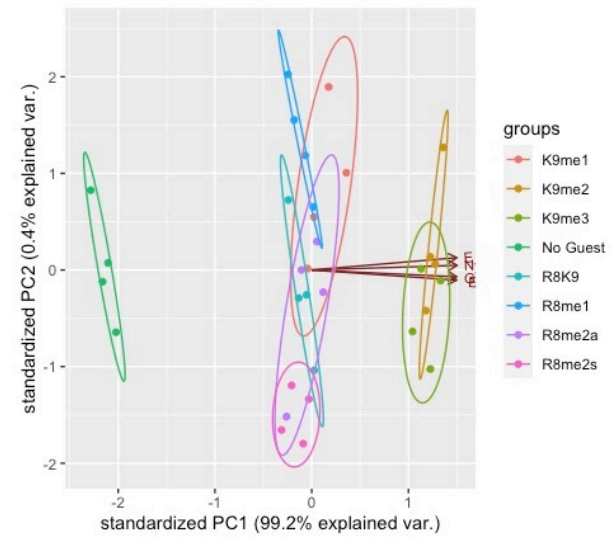

Figure S10. PCA plots resulting from Method B assays with a 1:1:5 ratio of BB:dye:peptide but varying concentrations of peptide. Peptide concentration of $200 \mathrm{nM}$ was also tested, but the associated dye concentration of $40 \mathrm{nM}$ resulted in fluorescence measurements with too much noise.

$1 \mathrm{hr}$

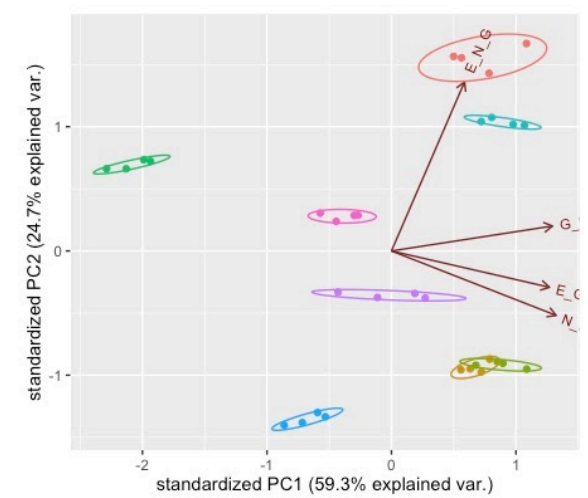

$2 \mathrm{hrs}$

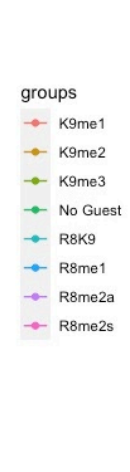

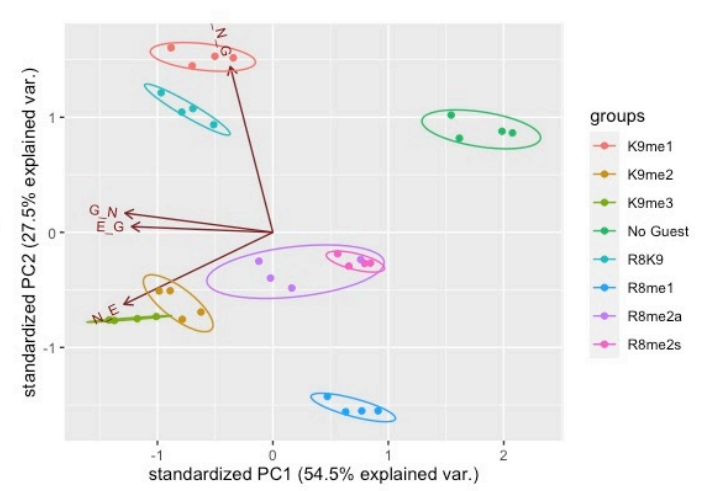

Figure S11. PCA plots resulting from Method $B$ assays with a 1:1:5 ratio of BB:dye:peptide with concentrations of $200 \mathrm{nM} \mathrm{BB}, 200 \mathrm{nM}$ dye, and $1 \mu \mathrm{M}$ peptide. Left: 1 hour between addition of peptide and fluorescence measurements. Right: 2 hours between addition of peptide and fluorescence measurements. 

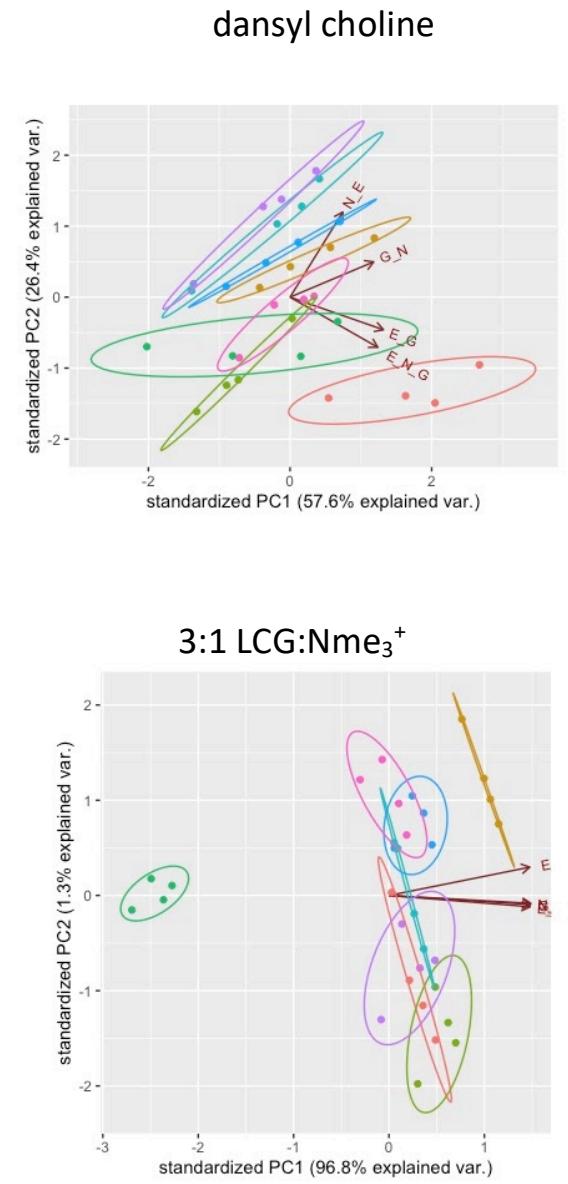
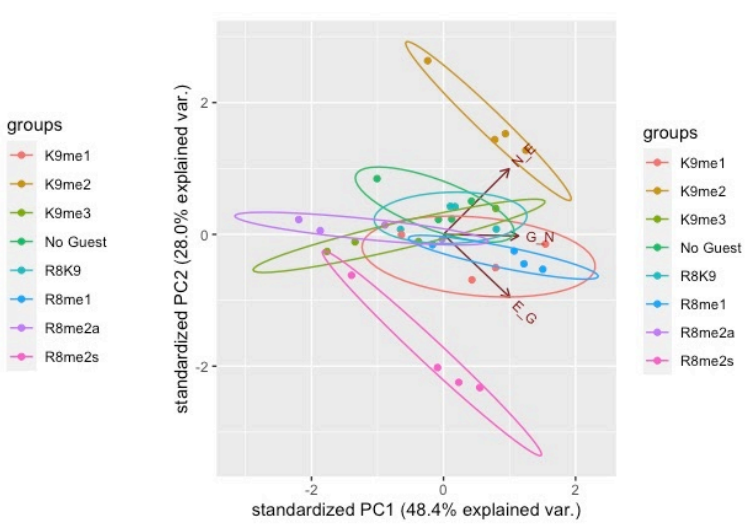

\section{1:1 LCG:FAM-Nme ${ }^{+}$}

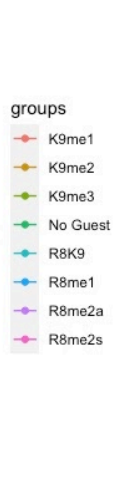

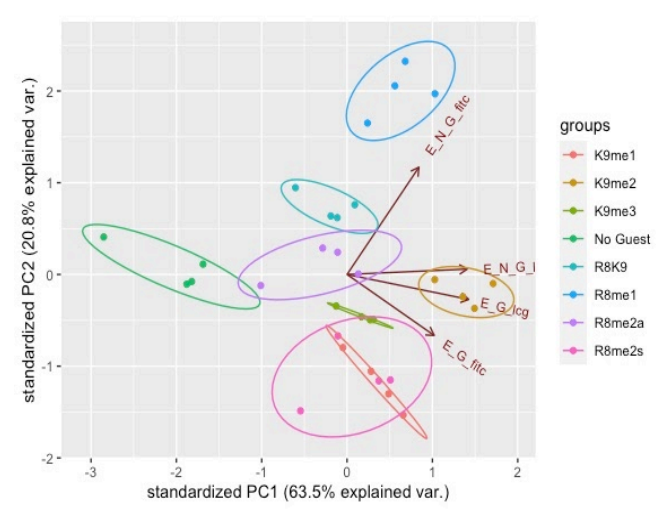

Figure S12. PCA plots resulting from Method B assays with a 1:1:5 ratio of BB:dye:peptide with concentrations of $200 \mathrm{nM} \mathrm{BB}, 200 \mathrm{nM}$ dye, and $1 \mu \mathrm{M}$ peptide. In each case, the dye or dye combination used is specified above the plot.

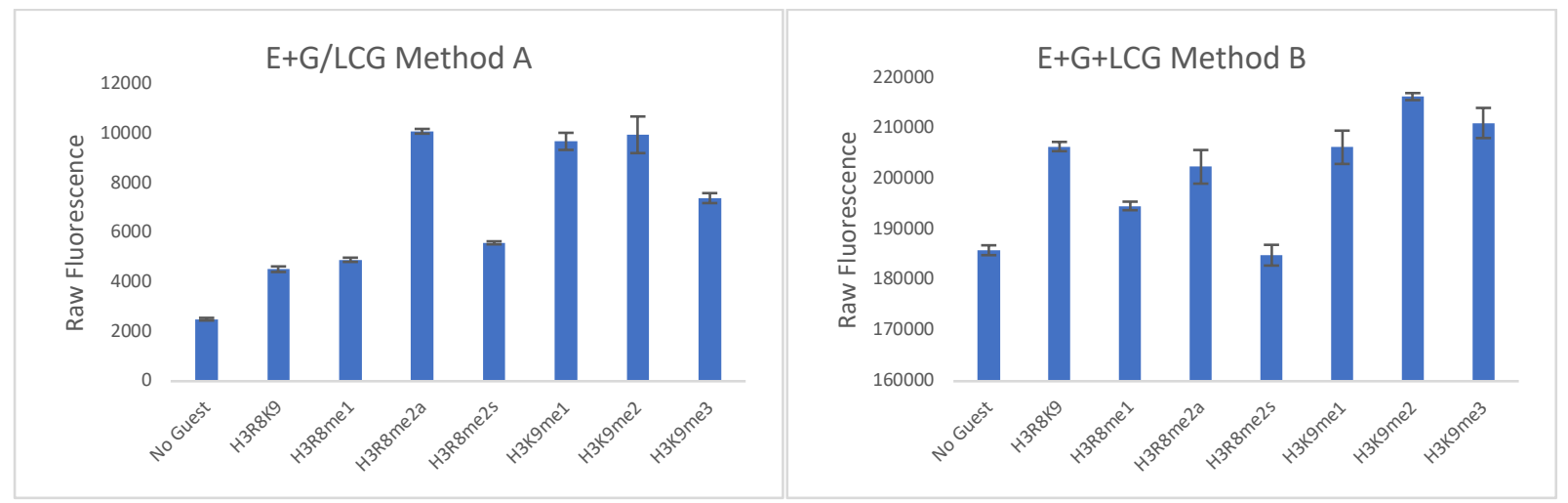

Figure S13. Comparison of averaged raw fluorescence values for each PTM using Method A analysis (left) and Method B analysis (right) with the E+G library and LCG as the indicator. 
Method B PCA Work-up and Sensor Array Identification.

(a)

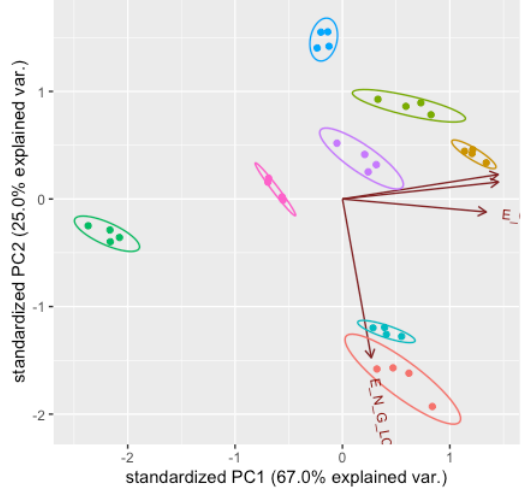

(c)
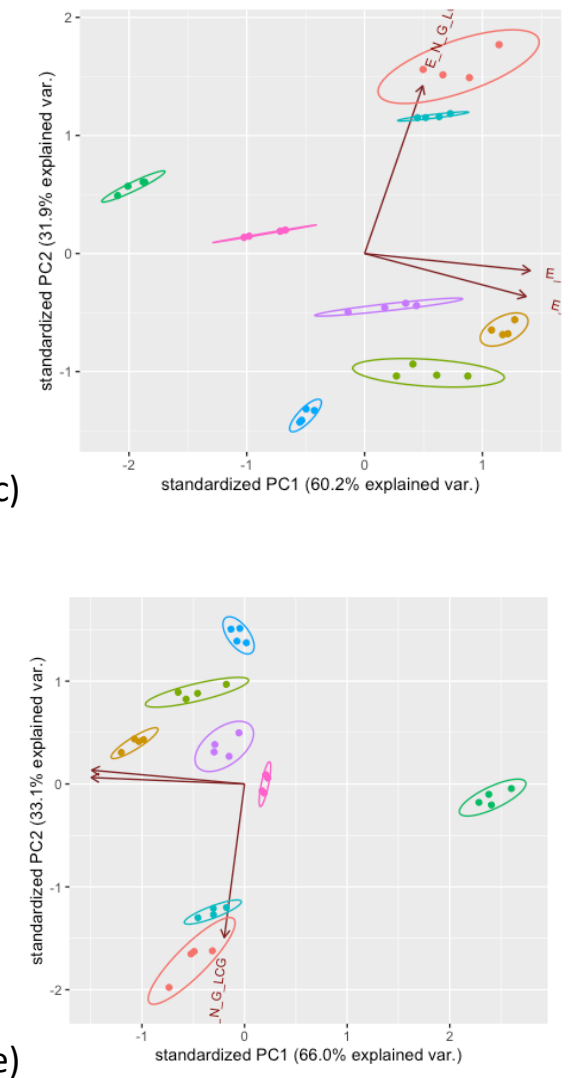

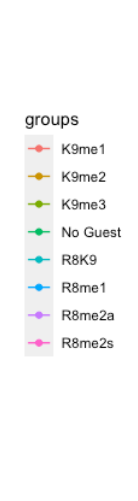

(b)
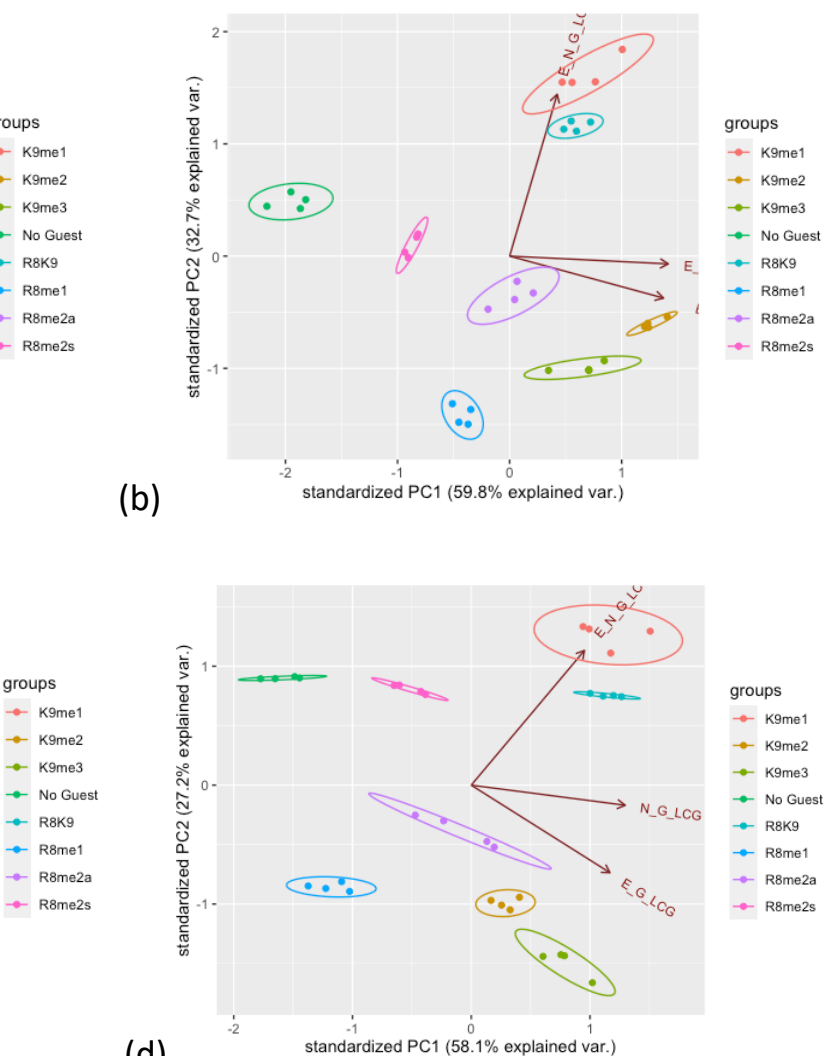

(d)
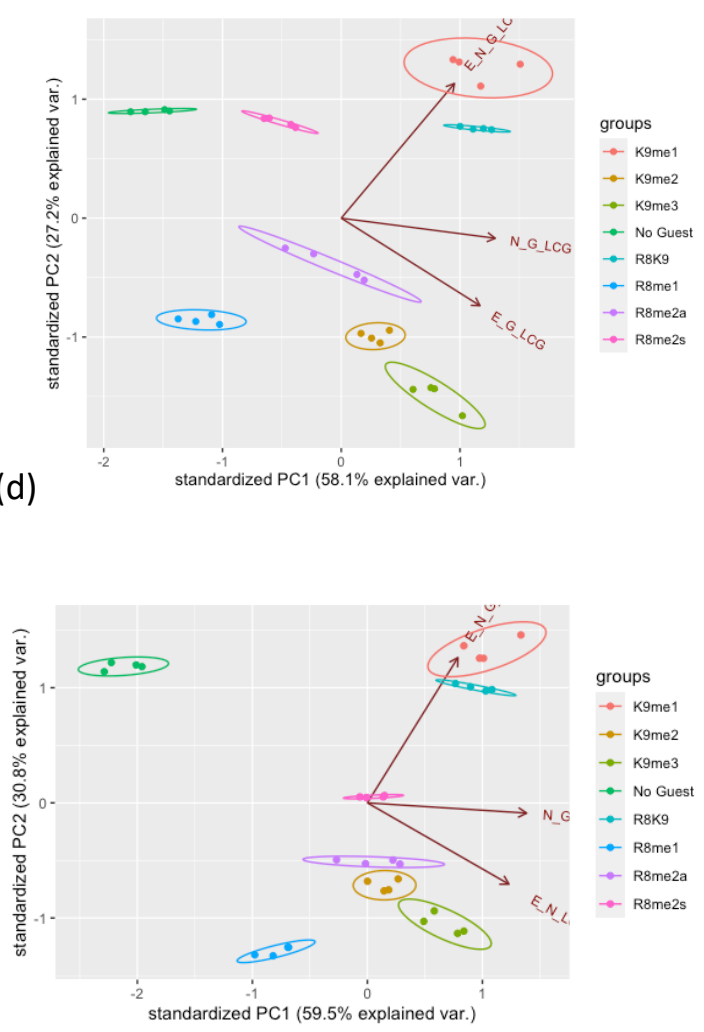

(f)

Figure S14. PCA plots from Method B DCL combinations that yielded full separation of all PTMs at $95 \%$ confidence. (a) $\mathrm{E}+\mathrm{G}+\mathrm{LCG}, \mathrm{E}+\mathrm{N}+\mathrm{G}+\mathrm{LCG}, \mathrm{E}+\mathrm{N}+\mathrm{LCG}+\mathrm{Nme}_{3}{ }^{+}, \mathrm{E}+\mathrm{N}+\mathrm{FAM}-\mathrm{Nme}_{3}{ }^{+}+\mathrm{LCG}$. (b) $\mathrm{E}+\mathrm{G}+\mathrm{LCG}$, $\mathrm{E}+\mathrm{N}+\mathrm{G}+\mathrm{LCG}, \mathrm{E}+\mathrm{N}+\mathrm{FAM}-\mathrm{Nme}_{3}{ }^{+}+\mathrm{LCG}$. (c) $\mathrm{E}+\mathrm{G}+\mathrm{LCG}, \mathrm{E}+\mathrm{N}+\mathrm{G}+\mathrm{LCG}, \mathrm{E}+\mathrm{N}+\mathrm{LCG}+\mathrm{Nme}_{3}{ }^{+}$. (d) $\mathrm{E}+\mathrm{G}+\mathrm{LCG}, \mathrm{N}+\mathrm{G}+\mathrm{LCG}$, $\mathrm{E}+\mathrm{N}+\mathrm{G}+\mathrm{LCG}$. (e) $\mathrm{E}+\mathrm{N}+\mathrm{G}+\mathrm{LCG}, \mathrm{E}+\mathrm{N}+\mathrm{LCG}+\mathrm{Nme}_{3}{ }^{+}, \mathrm{E}+\mathrm{N}+\mathrm{FAM}-\mathrm{Nme}_{3}{ }^{+}+\mathrm{LCG}$. (f) $\mathrm{N}+\mathrm{G}+\mathrm{LCG}, \mathrm{E}+\mathrm{N}+\mathrm{G}+\mathrm{LCG}$, $\mathrm{E}+\mathrm{N}+\mathrm{LCG}+\mathrm{Nme}_{3}{ }^{+}$. 


\section{Supplementary Information References}

S1. Hamieh, S.; Saggiomo, V.; Nowak, P.; Mattia, E.; Ludlow, R. F.; Otto, S. A "Dial-A-Receptor" Dynamic Combinatorial Library. Angew. Chemie Int. Ed. 2013, 52 (47), 12368-12372.

S2. West, K. R.; Ludlow, R. F.; Corbett, P. T.; Besenius, P.; Mansfeld, F. M.; Cormack, P. A. G.; Sherrington, D. C.; Goodman, J. M.; Stuart, M. C. A.; Otto, S. Dynamic combinatorial discovery of a [2]-catenane and its template-induced conversion into a molecular square synthetic receptor. J. Am. Chem. Soc. 2008, 130 (33), 10834-10835.

S3. Pinkin, N. K.; Waters, M. L. Development and mechanistic studies of an optimized receptor for trimethyllysine using iterative redesign by dynamic combinatorial chemistry. Org. Biomol. Chem. 2014, 12 (36), 7059-7067.

S4. Liu, Y.; Liao, P.; Cheng, Q.; Hooley, R.J. Protein and Small Molecule Recognition Properties of Deep Cavitands in a Supported Lipid Membrane Determined by Calcination-Enhanced SPR Spectroscopy. J. Am. Chem. Soc. 2010, 132, 10383.

S5. Peacor, B. C.; Ramsay, C. M.; Waters, M. L. Fluorogenic sensor platform for the histone code using receptors from dynamic combinatorial libraries. Chem. Sci., 2017, 8, 1422-1428.

S6. Ferguson, J. and A. W. H. Mau. Absorption studies of acid-base equilibria of dye solutions. Chem. Phys. Lett. 1972, 17, 543-546.

S7. Groenning, M. Binding mode of Thioflavin T and other molecular probes in the context of amyloid fibrils-current status. J. Chem. Biol. 2010, 3 (1), 1-18.

S8. Tsuda, T.; Kaya, S.; Funatsu, H.; Hayashi, Y.; Taniguchi, K. Fluorescein 5'-Isothiocyanate-Modified Na+, $\mathrm{K}^{+}$-ATPase, at Lys-501 of the $\alpha$-Chain, Accepts ATP Independent of Pyridoxal 5'-Diphospho-5'-Adenosine Modification at Lys-480. J. Biochem. 1998, 123 (1), 169-174.

S9. Chen, R. F. Dansyl labeled proteins: Determination of extinction coefficient and number of bound residues with radioactive dansyl chloride. Anal. Biochem. 1968, 25 (1), 412-416.

S10. Pace, C. N.; Vajdos, F.; Fee, L.; Grimsley, G.; Gray, T. How to measure and predict the molar absorption coefficient of a protein. Protein Sci. 1995, 4, 2411-2423.

S11. Mullins, A. G.; Pinkin, N. K.; Hardin, J. A.; Waters, M. L. Achieving High Affinity and Selectivity for Asymmetric Dimethylarginine by Putting a Lid on a Box. Angew. Chem. Int. Ed. 2019, 58 (16), 5285-5285. 